\title{
hERG Blockade by Iboga Alkaloids
}

\author{
Kenneth Alper $\cdot$ Rong Bai $\cdot$ Nian Liu $\cdot$ \\ Steven J. Fowler $\cdot$ Xi-Ping Huang $\cdot$ Silvia G. Priori • \\ Yanfei Ruan
}

Published online: 31 January 2015 18-methoxycoronaridine, a product of rational synthesis and current focus of drug development was $>50 \mu \mathrm{M}$. hERG blockade was voltage dependent for all of the compounds, consistent with low-affinity blockade. hERG channel binding affinities $\left(K_{\mathrm{i}}\right)$ for the entire set of compounds, including 18-MC, ranged from 0.71 to $3.89 \mu \mathrm{M}$, suggesting that $18-\mathrm{MC}$ binds to the hERG channel with affinity similar to the other compounds, but the interaction produces substantially less hERG blockade. In view of the extended half-life of noribogaine, these results may relate to observations of persistent QT prolongation and cardiac arrhythmia at delayed intervals of days following ibogaine ingestion. The apparent structure-activity relationships regarding positions of substitutions on the ibogamine skeleton suggest that the iboga alkaloids might provide an informative paradigm for investigation of the structural biology of the hERG channel.

Keywords Toxicology $\cdot$ hERG $\cdot$ Iboga alkaloid . Ibogaine $\cdot$ Noribogaine $\cdot 18$-Methoxycoronaridine (18-MC)

\section{Introduction}

The iboga alkaloids are a class of approximately 80 known naturally occurring and synthetic monoterpene indole alkaloids that are defined structurally on the basis of a common ibogamine skeleton (Fig. 1) [1, 2]. Some iboga alkaloids reportedly reduce the self-administration of drugs of abuse and opiate withdrawal symptoms in animal models and humans $[3,4]$. Ibogaine, the prototypic iboga alkaloid is used in medical and nonmedical settings for the treatment of substance use disorders. Ibogaine is illegal in the USA and several EU countries due to its classification as a hallucinogen, and unregulated in most of the rest of the 


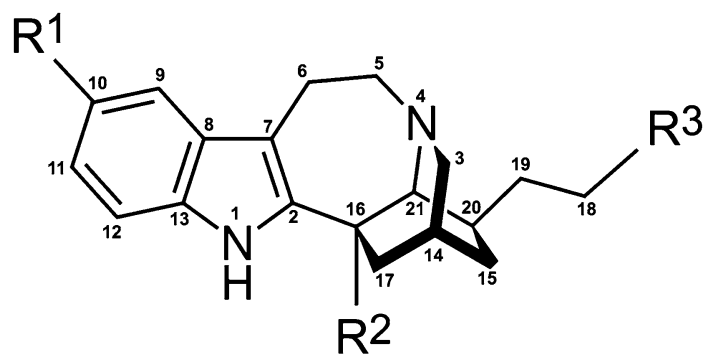

\begin{tabular}{|l|c|c|c|}
\hline Iboga alkaloid & $\mathbf{R}^{1}$ & $\mathbf{R}^{\mathbf{2}}$ & $\mathbf{R}^{\mathbf{3}}$ \\
\hline Ibogaine & $\mathrm{OCH}_{3}$ & $\mathrm{H}$ & $\mathrm{H}$ \\
\hline Noribogaine & $\mathrm{OH}$ & $\mathrm{H}$ & $\mathrm{H}$ \\
\hline Voacangine & $\mathrm{OCH}_{3}$ & $\mathrm{CO}_{2} \mathrm{CH}_{3}$ & $\mathrm{H}$ \\
\hline 18-Methoxycoronaridine & $\mathrm{H}$ & $\mathrm{CO}_{2} \mathrm{CH}_{3}$ & $\mathrm{OCH}_{3}$ \\
\hline
\end{tabular}

Fig. 1 Chemical structures of ibogaine, noribogaine, voacangine, and 18-MC. The positions of R1, R2, and R3 on the ibogamine parent structural skeleton are numbered 10, 16, and 18, respectively, according to the Le Men and Taylor system

world, where it is neither illegal nor officially approved. The collective settings of ibogaine use have been termed a "medical subculture" [5] or a "great uncontrolled experiment" [6]. Nonetheless, in view of evidence for a novel mechanism of action, the search for targets of iboga alkaloids may be informative regarding the neurobiology of addiction and the development of fundamentally innovative treatment $[3,4,7,8]$.

Ibogaine is most often used for the specific indication of opioid detoxification, and typically administered as a large single dose in the range of $10-25 \mathrm{mg} / \mathrm{kg}[5,9,10]$. Fatalities have occurred temporally related to the use of ibogaine. Nineteen such fatalities are known to have occurred between 1991 and 2009 [11], most of which were associated with commonly abused substances and preexisting medical comorbidities, particularly cardiovascular. Subsequent clinical reports have demonstrated prolongation of the QT interval and/or polymorphic ventricular tachyarrhythmias (PVTs) [12-15] including torsades de pointes (TdP) [16].

The major cause of drug-induced TdP is the blockade of a voltage-gated cardiac potassium channel [17], the poreforming subunit of which is encoded by the human ether-ago-go-related gene (hERG) [18]. The hERG channel conducts the efflux of potassium from the cardiac myocyte that is the basis of the rapid delayed rectifier current $(\mathrm{IKr})$ during the repolarization phase of the cardiac action potential. hERG channel blockade impairs cardiac repolarization, resulting in prolongation of the QT interval and PVTs, including TdP. Consistent with observations of QT prolongation and TdP, Ibogaine blocks the hERG channel with reported $\mathrm{IC}_{50}$ in the low micromolar range $[19,20]$.

Ibogaine is most frequently used in the hydrochloride form and is produced by one of two methods. One method involves extraction from the root bark of the West African shrub Tabernanthe iboga Baill. (Apocynaceae family).
This has been the most frequent method of manufacture in the present settings of ibogaine use [5]. The purity of this material is typically approximately $95 \%$, which raises the toxicological question of trace impurities as an additional possible determinant of hERG blockade. More recently, Ibogaine $\mathrm{HCl}$ has become available that has been produced by the route of semisynthesis via voacangine (Fig. 1), which can yield higher purity on the order of $\geq 99.5 \%$.

Noribogaine is ibogaine's principal metabolite, the product of demethylation of ibogaine (Fig. 1) via hepatic cytochrome P450 2D6 (CYP2D6). The half-life $\left(T_{1 / 2}\right)$ of ibogaine in humans is estimated to be 4-7 $\mathrm{h}[9,21]$, and the $T_{1 / 2}$ of noribogaine is apparently considerably longer than that of the parent compound, possibly on the order of days [22-24]. The question of hERG blockade by noribogaine is of interest in view of observations of persistent QT prolongation and arrhythmia for days following the ingestion of ibogaine $[13,15,16]$.

18-Methoxycoronaridine (18-MC) is a product of rational pharmaceutical synthesis that differs from ibogaine at three of the 21 positions on the ibogamine skeleton (Fig. 1). 18-MC is reported to produce less hERG blockade than ibogaine [25]. The National Institute on Drug Abuse (NIDA) has recently committed over 6 million USD to support preclinical testing and chemical manufacturing and control work intended to eventually enable clinical trials for the development of 18-MC [8]. However, ibogaine is the iboga alkaloid that has been commonly used for the treatment of addiction.

In the present study, we evaluated hERG blockade and binding affinities for the hERG channel of iboga alkaloids. We evaluated blockade of the hERG channel by noribogaine, and compared ibogaine produced by extraction from T. iboga versus a sample of higher purity produced by semisynthesis via voacangine. Collectively, the data from this set of compounds appear to allow some tentative structural hypotheses regarding positions on the ibogamine structural skeleton in relation to the effect of hERG blockade.

\section{Methods}

Chemicals

Ibogaine $\mathrm{HCl}$ (purity $=95 \%$ ) produced by extraction of T. iboga root bark was obtained from Slater \& Frith Ltd, Wroxham Norwich, UK. Ibogamine was the major impurity in this sample, with lesser amounts of tabernanthine and ibogaline. Ibogaine $\mathrm{HCl}$ (purity $=99.5 \%$ ) obtained by conversion from voacangine, and voacangine (purity $>99 \%$ ) were obtained from Phytostan Enterprises, Inc., Montreal, Quebec. Noribogaine (purity $=99.2 \%$ ) was 
obtained from Slater \& Frith Ltd. 18-MC $\mathrm{HCl}$ (purity $>99 \%$ ) was from Obiter Research LLC, Champaign, IL. The purities of iboga alkaloids are stated on certificates of analyses and verified by the available manufacturer's HPLC documentation and/or HPLC-MS or GC-MS in the laboratory of Martin Kuehne, Department of Chemistry, University of Vermont, Burlington, Vermont [7].

\section{Transfection in HEK Cells}

hERG cDNA was subcloned into the pcDNA3.1 vector (Invitrogen, Carlsbad, USA). Human embryonic kidney 293 (HEK293) cells were cultured in minimum essential medium (MEM) supplemented with $10 \%$ fetal bovine serum, $1 \mathrm{mM}$ sodium pyruvate, $0.1 \mathrm{mM}$ non-essential amino acid solution, $100 \mathrm{U} / \mathrm{ml}$ penicillin, and $100 \mathrm{mg} / \mathrm{ml}$ streptomycin sulfate in $5 \% \mathrm{CO}_{2}$ incubator at $37{ }^{\circ} \mathrm{C}$. HEK293 cells were transiently transfected with $0.9 \mu \mathrm{g}$ of WT-hERG using Lipofectamine according to the manufacture's instruction (Invitrogen, California, USA). $0.15 \mu \mathrm{g}$ of eGFP plasmid was co-transfected to monitor transfection efficacy. To examine the blocking effect of ibogaine and its derivatives on hERG channel, HEK293 cells were harvested at $36 \mathrm{~h}$ after transfection and seeded onto a glass coverslip. After 12-24 h, the cell-attached coverslips were used for electrophysiological recordings.

\section{Electrophysiology}

Membrane currents were measured using whole-cell patch clamp procedures with Axopatch 200B amplifiers (Axon Instruments, Foster City, CA, USA). Internal pipette solution contained $130 \mathrm{mM} \mathrm{KCl}, 1 \mathrm{mM} \mathrm{MgCl}_{2}, 5 \mathrm{mM}$ EGTA, $5 \mathrm{mM} \mathrm{MgATP}$, and $10 \mathrm{mM}$ HEPES with $\mathrm{pH} 7.2$ adjusted with $\mathrm{KOH}$. External solutions consisted of $137 \mathrm{mM} \mathrm{NaCl}, 4 \mathrm{mM} \mathrm{KCl}, 1.8 \mathrm{mM} \mathrm{CaCl}_{2}, 1 \mathrm{mM} \mathrm{MgCl}_{2}$, $10 \mathrm{mM}$ glucose, and $10 \mathrm{mM}$ HEPES with $\mathrm{pH} 7.4$ adjusted with $\mathrm{NaOH}$. Recordings were made at room temperature.

Concentration-response curves were tested for iboga alkaloids. The IKr current was elicited from a holding potential of $-80 \mathrm{mV}$ by a depolarizing pulse to $20 \mathrm{mV}$ for $4 \mathrm{~s}$ and then followed by a repolarization step to $-50 \mathrm{mV}$ for $4 \mathrm{~s}$ to evoke tail current (Itail). The IKr current was first recorded when superfused with extracellular solution without drug (control condition), then the same cell was superfused with extracellular solution containing a giving concentration of the tested drug, and current was recorded after steady state was achieved in the presence of drug. The tail current recorded in the presence of drug is compared with the current recorded without drug, and the decreased percentage is marked as the blocking effect of the tested drug. Concentration-response curves were fitted with the following equation: $\mathrm{I} / \mathrm{Imax}=1 / 1+\left[(\mathrm{drug}) / \mathrm{IC}_{50}\right]^{n}$.
The current-voltage relationships of $\mathrm{IKr}$ were tested after depolarizations from -60 to $50 \mathrm{mV}$ in $10 \mathrm{mV}$ increments from a holding potential of $-80 \mathrm{mV}$ in the absence or presence of the iboga alkaloids. Ibogaine from either source, and noribogaine and voacangine was all evaluated at a concentration of $3 \mu \mathrm{M}$. Because the effect on $\mathrm{IKr}$ of $18-\mathrm{MC}$ at a concentration of $3 \mu \mathrm{M}$ was negligible, we tested the effect of 18-MC at a concentration of $10 \mu \mathrm{M}$.

\section{Radioligand Binding Assays}

The radioligand binding assay methodology has been described elsewhere $[26,27]$. Briefly, membrane pellets for radioligand binding assays were prepared from HEK 293 cells stably expressing hERG channels. Inhibition of $\left[{ }^{3} \mathrm{H}\right]$ Dofetilide $(2 \mathrm{nM})$ binding to the hERG channel was carried out in the absence (total binding) and presence of increasing concentrations of iboga alkaloids $(0.1-10,000 \mathrm{nM})$ in 96-well plates, with final volume of $125 \mathrm{ml}$ per well-binding buffer (10 mM HEPES, $135 \mathrm{mM} \mathrm{NaCl}, 5 \mathrm{mM} \mathrm{KCl}, 0.8 \mathrm{mM}$ $\mathrm{MgCl}_{2}, 1 \mathrm{mM}$ EGTA, $1 \mathrm{mg} / \mathrm{ml} \mathrm{BSA}, \mathrm{pH}$ 7.4). Bound radioligand was captured by filtration onto glass fiber filter paper, and radioactivity retained on the filter was counted in a MicroBeta TriLux plate counter. Results were analyzed in GraphPad Prism with the built-in one-site inhibition binding function to obtain binding affinity $\left(K_{\mathrm{i}}\right)$. Affinity values are presented as mean from a minimum of two independent assays, each in triplicate.

\section{Statistical Analysis}

Pclamp9.2 (Axon Instruments) and Excel (Microsoft, Seattle, Wash) were used for data acquisition and analysis. Data are presented as mean $\pm \mathrm{SE}$. An unpaired Student $t$ test and one-way ANOVA were used to compare means. Values of $p<0.05$ were considered statistically significant.

\section{Results}

Concentration-Response Relationships

$99.5 \%$ ibogaine manufactured by semisynthesis via voacangine blocked hERG with $\mathrm{IC}_{50} \quad 4.09 \pm 0.69 \mu \mathrm{M}$ ( $n=14$ ) (Figs. 2a, 3a). IC IC $_{50}$ for hERG blockade by $95 \%$ ibogaine manufactured by extraction from $T$. iboga was $3.53 \pm 0.16 \mu \mathrm{M}(n=10)$ (Fig. $3 b)$. There was no difference for $\mathrm{IC}_{50}$ of ibogaine produced by the two respective methods of manufacturing ( $t=0.67, d f=23 ; p=.51)$.

Noribogaine blocked the hERG channel with an $\mathrm{IC}_{50}$ of $2.86 \pm 0.68 \mu \mathrm{M}(n=11$, Figs. $2 \mathrm{~b}, 3 \mathrm{c})$. Similar to ibogaine and noribogaine, voacangine blocked the hERG channel with an $\mathrm{IC}_{50}$ of $2.25 \pm 0.34 \mu \mathrm{M}(n=6)$ (Fig. $\left.3 \mathrm{~d}\right), \mathrm{IC}_{50}$ 
Fig. 2 Effect on hERG

blockade of: a ibogaine (99.5\% purity), and $\mathbf{b}$ noribogaine.

Original current recording in the same cell with control (red), $1 \mu \mathrm{M}$ (black), $10 \mu \mathrm{M}$ (blue), and after washout (green). c Effect of 18-MC on hERG blockade: (left) original current recording in the same cell with control (red), $10 \mu \mathrm{M}$ (black), $100 \mu \mathrm{M}$ (teal), and after washout (green); (right) 18-MC at concentrations of 10 and $100 \mu \mathrm{M}$ reduced $\mathrm{IKr}$ by $12.8 \pm 1.8$ and $57.8 \pm 4.7 \%$, respectively (Color figure online)
A lbogaine, $99.5 \%$
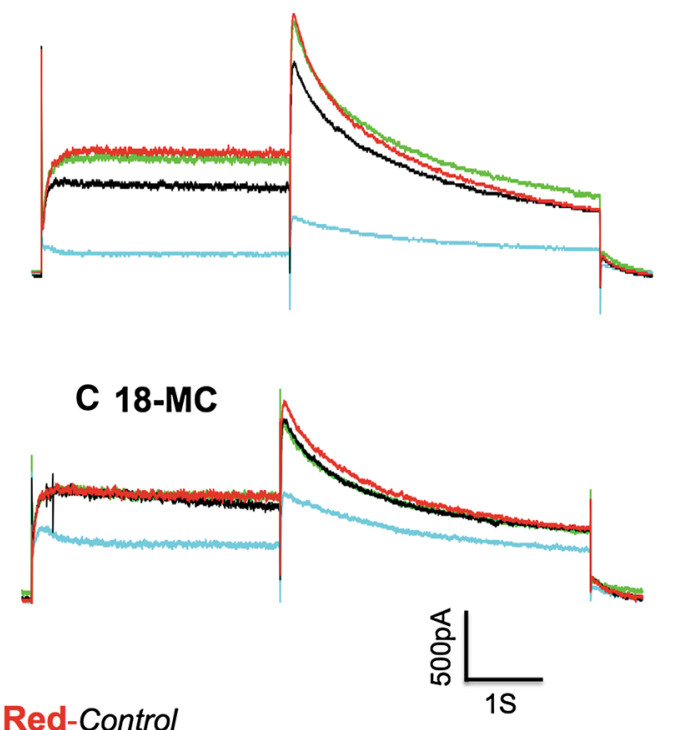

Green-Washout

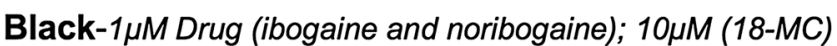

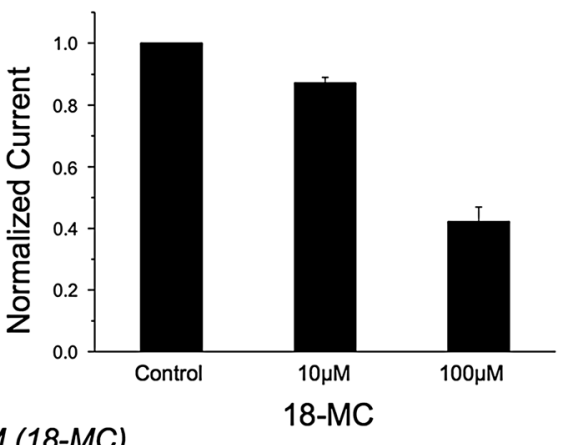

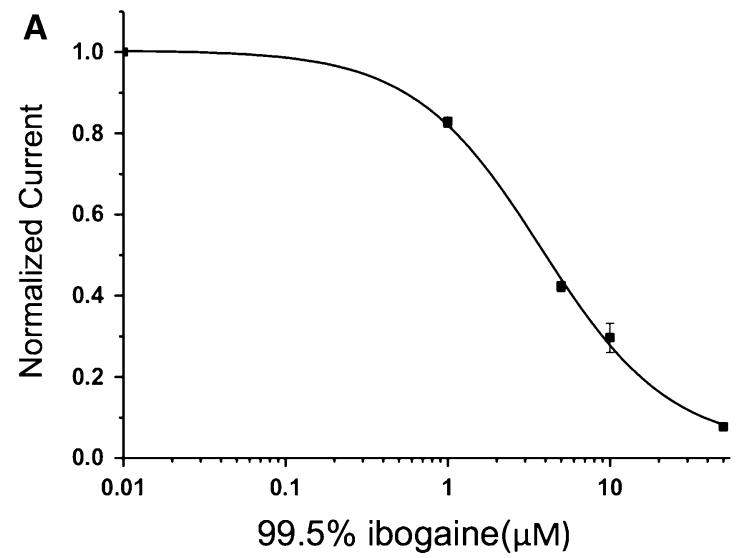
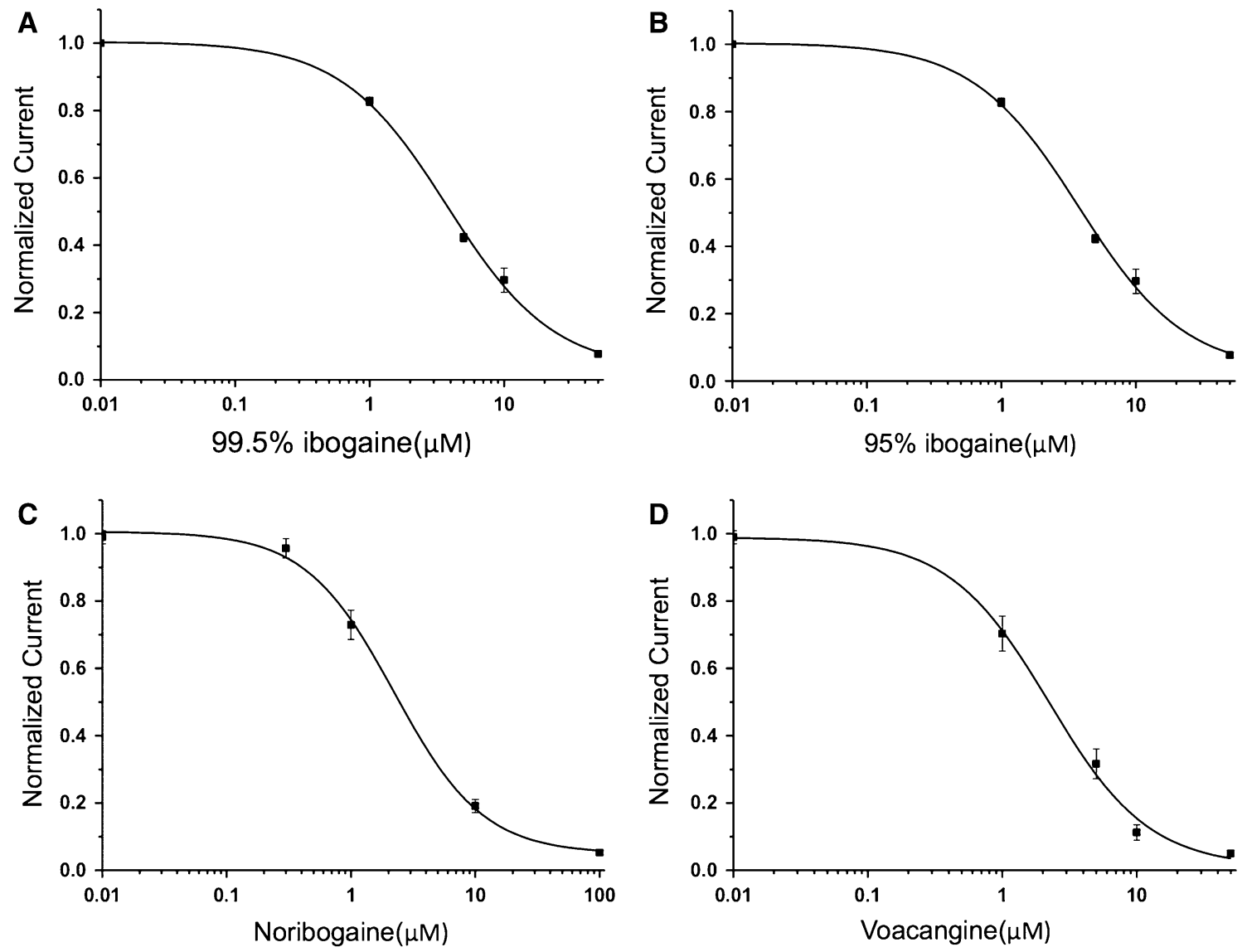

Fig. 3 Concentration-response curves for hERG blockade by iboga alkaloids: a ibogaine $99.5 \%$ purity produced by semisynthesis via voacangine, b ibogaine $95 \%$ purity produced by extraction from $T$. iboga root bark, c noribogaine, and d vocangaine 
did not differ among ibogaine produced by either manufacturing method, noribogaine, and voacangine (one-way ANOVA, $F_{3,27}=1.53 ; p=.22$ ).

In contrast to the other compounds, 18-MC showed much less potent hERG blockade. Concentrations of 10 and $100 \mu \mathrm{M}$ decreased $\mathrm{IKr}$ current by $12.8 \pm 1.8$ and $57.8 \pm 4.7 \%$, respectively $(n=9)$ (Fig. 2 c). We observed precipitation with higher concentrations of 18-MC in Tyrode solution, which limited the accuracy of the measurement of $\mathrm{IC}_{50}$. We estimate that the $\mathrm{IC}_{50}$ of $18-\mathrm{MC}$ is between 50 and $100 \mu \mathrm{M}$.

\section{Current-Voltage Relationships}

hERG blockade was studied across the range of voltages between $-60 \mathrm{mV}$ and $50 \mathrm{mV}$ in $10 \mathrm{mV}$ increments (Fig. 4). Tail current density did not differ significantly among control and drug-treated conditions at any voltages below $10 \mathrm{mV}$. Tail current density differed significantly among control and drug-treated conditions at $10 \mathrm{mV}$ (one-way ANOVA, $F_{5,56}=2.78 ; p=0.025$ ), and differences were all highly significant at voltages of $20 \mathrm{mV}$ or greater $(p<0.001)$.

hERG blockade was voltage dependent for all of the compounds. However, there was no significant difference between the control and $10 \mu \mathrm{M} 18-\mathrm{MC}$ at any voltage. The values for blockade of tail current at $20 \mathrm{mV}$ by $99.5 \%$ ibogaine, and $95 \%$ ibogaine were $42 \pm 5.2 \%(n=6)$ and $45 \pm 5.6 \% \quad(n=4), \quad$ respectively. Noribogaine, voacangine, and 18-MC blocked of tail current at $20 \mathrm{mV}$ with respective values of $52 \pm 6.4 \%(n=5), 54 \pm 2.7 \%$ $(n=9)$ and $13 \pm 3.0 \%(n=7)$.

\section{Radioligand Binding Assays}

$K_{\mathrm{i}}$ values $(\mu \mathrm{M})$ were as follows: ibogaine $(99.5 \%$ purity) $=0.71 \pm 0.13$; noribogaine $=1.96 \pm 0.36$; voacangine $=3.89 \pm 0.69$; and $18-\mathrm{MC}=3.12 \pm 0.60$.

\section{Discussion}

In the present study, we evaluated hERG blockade by ibogaine, 18-MC, noribogaine, and voacangine utilizing the whole-cell patch clamp technique. Noribogaine blocked the hERG channel with potency comparable to that of its parent compound. Ibogaine produced by extraction from $T$. iboga root bark or as a purer product of semisynthesis via voacangine produced similar hERG blockade. Collectively, the set of compounds suggests possible structure-function inferences regarding the relatively less hERG blockade associated with 18-MC.

The values for $\mathrm{IC}_{50}$ of ibogaine and noribogaine appear clinically relevant. The $\mathrm{IC}_{50}$ values for $99.5 \%, 95 \%$ ibogaine, and noribogaine were $4.09,3.53$, and $2.86 \mu \mathrm{M}$, respectively. In a sample of 24 subjects that were orally administered ibogaine dosages of $10 \mathrm{mg} / \mathrm{kg}$, mean peak blood levels for ibogaine and noribogaine, respectively,
Fig. 4 Current-voltage relationships for hERG blockade by iboga alkaloids. Left original recordings of $\mathrm{IKr}$ under control conditions (for each compound, the control recording is to the left of the test compound recording) with extracellular solution containing $3 \mu \mathrm{M}$ ibogaine $99.5 \%$ purity (a), ibogaine $95 \%$ purity (b), noribogaine (c), and vocangaine (d); and $10 \mu \mathrm{M} 18-\mathrm{MC}$ (e). Right the current-voltage curve of the tail currents under control conditions (empty symbol) and with $3 \mu \mathrm{M}$ ibogaine $99.5 \%$, ibogaine $95 \%$, noribogaine, and voacangine; and $10 \mu \mathrm{M}$ 18-MC. $n=4$ to 9 cells

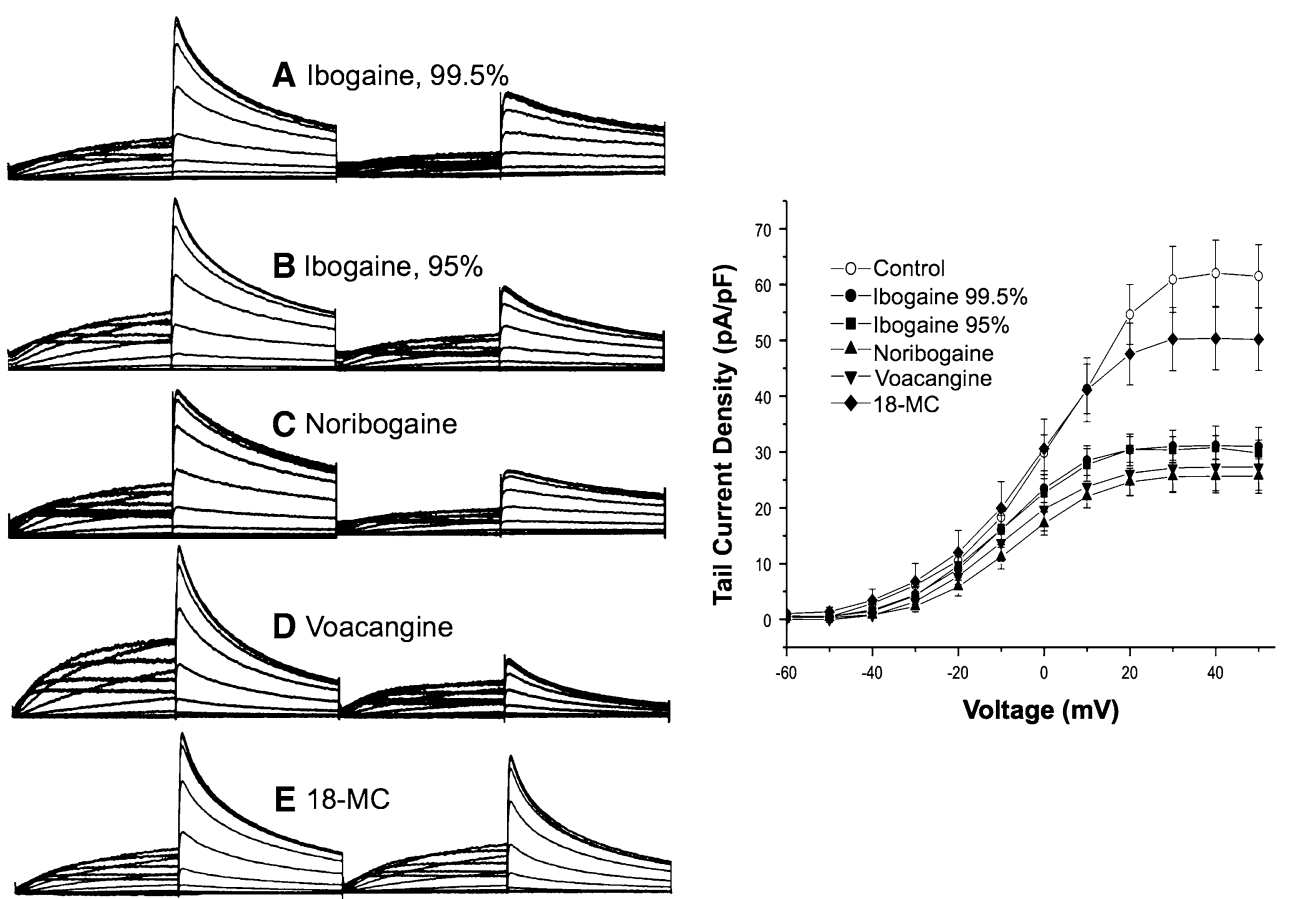


were 2.4 and $3.2 \mu \mathrm{M}$ [9]. A protocol consisting of single large orally administered dose is clinically representative; ibogaine is commonly administered for opiate detoxification as a single dose in the range of $10-25 \mathrm{mg} / \mathrm{kg}[5,10,11]$. From a postmortem series of 19 fatalities, the subset of 10 cases in which blood ibogaine levels was available, the mean was $7.6 \mu \mathrm{M}$ (range $0.77-30 \mu \mathrm{M}$ ), and in the two cases for which they were available, noribogaine levels were 13.4 and $18.8 \mu \mathrm{M}$ [11]. Although the interpretation of levels from postmortem studies may be complicated by redistribution, and taking into account that ibogaine is $65 \%$ protein bound [25], ibogaine or noribogaine may produce significant hERG channel blockade at clinically relevant concentrations [25]. There is apparently no published data regarding the fraction of noribogaine that is protein bound.

The clearance of noribogaine is prolonged relative to ibogaine. A study on 24 human volunteers that excluded CYP2D6 slow metabolizers found ibogaine $T_{1 / 2}=7.45 \mathrm{~h}$ following the administration of a fixed dose of $800 \mathrm{mg}$ ibogaine $\mathrm{HCl}$ [9]. In this same sample, the half-life of noribogaine was reported as not quantifiable, but individual $24 \mathrm{~h}$ blood versus concentration curves published separately appear to indicate $T_{1 / 2}$ well beyond one day $[22,23]$. In a subsequent study in which human volunteers received single doses of noribogaine ranging from 3 to $60 \mathrm{mg}, T_{1 / 2}$ for noribogaine ranged from 28 to $49 \mathrm{~h}$ [24]. A single dose of $60 \mathrm{mg}$ noribogaine produced a mean peak blood level of $0.39 \mu \mathrm{M}$ [24], and repeated administration would be expected to produce higher steady state levels in view of the extended $T_{1 / 2}$ of noribogaine.

Clinically, hERG blockade by noribogaine, in view of its extended $T_{1 / 2}$ may relate to the occurrence of arrhythmias or fatalities at an extended interval following the ingestion of ibogaine. Deaths at intervals of days after ingestion of ibogaine occur at a time when it would be expected that most ibogaine would be metabolized to noribogaine. For example, in a recent case report, QTc remained $>500 \mathrm{~ms}$ for 4 days following administration of ibogaine [15]. In another case of well-characterized TdP and pause-dependent PVT, runs of PVT persisted into the fifth hospital day [16]. In the series of 19 fatalities, the interval between ingestion and death ranged from 1.5 to $76 \mathrm{~h}$, with a mean of $24 \mathrm{~h} \mathrm{[11].}$

Ibogaine $\mathrm{HCl} 95 \%$ produced by extraction from $T$. $i b$ oga root bark is the purity and method of manufacture that has been most commonly used clinically [5]. This $95 \%$ ibogaine and the $99.5 \%$ ibogaine produced by semisynthesis via voacangine produced similar levels of hERG blockade. From a toxicological perspective, the very similar hERG blockade by either ibogaine sample appears to indicate that the observed hERG blockade is due to ibogaine itself and not to a trace impurity. Ibogaine hydrochloride form either source utilized in this study is relatively pure in contrast to crude alkaloid extracts or dried root bark from $T$. iboga $[5,11]$. The frequency of fatalities $[5,11,28,29]$ or serious cardiac arrhythmias [12$14]$ in cases involving the use of alkaloid extracts or dried T. iboga root bark suggests the possibility that these crude forms may contain toxicologically relevant compounds in addition to ibogaine.

Our findings of $\mathrm{IC}_{50}$ values of $4.09 \mu \mathrm{M}$ and $3.53 \mu \mathrm{M}$, respectively, for $99.5 \%$ ibogaine and $95 \%$ ibogaine agree well with a previous study that reported an $\mathrm{IC}_{50}$ value for ibogaine of $4 \mu \mathrm{M}$ in TSA-201 cells heterologously expressing hERG [19]. However, our finding of an 18-MC $\mathrm{IC}_{50}$ value $>50 \mu \mathrm{M}$ differs somewhat from a previously reported value of $14.9 \mu \mathrm{M}$ [25]. This previously published value for the $\mathrm{IC}_{50}$ of 18-MC was reportedly determined as in the prior study that had reported on ibogaine [19]. However, the more salient feature may be the apparent general agreement of our present findings with the previously published data indicating that 18 -MC produces substantially less hERG blockade than ibogaine [19, 25].

The concept of "repolarization reserve" [30] clinically contextualizes hERG blockade to multifactorial determinants of cardiac rhythm instability. Typically, druginduced TdP occurs in the clinical setting of multiple factors in addition to hERG blockade that diminish cardiac stability [17]. Among fatalities temporally related to ingestion of ibogaine, factors in addition to hERG blockade that diminish repolarization reserve are frequently present. Hypokalemia appears to be particularly important, as in a case involving severe depletion of potassium due to very aggressive use of cathartics as part of a "cleansing" regimen prior to treatment, an example that also illustrates the idiosyncratic hazards associated with the unconventional settings in which ibogaine is often administered [16].

Additional factors that commonly diminish repolarization reserve in chronic substance-related disorders include various co-ingestants, cardiac disease, and systemic medical conditions such as liver or respiratory disease, seizures, hypomagnesemia, or withdrawal from cocaine or alcohol $[17,31-33]$. These factors are frequently present in cases of arrhythmia or fatalities associated with the ingestion of ibogaine [11-13, 16]. Additional case reports have involved other significant, diverse comorbidities, such as a patient with an automatic implantable cardioverter defibrillator [28, 29], or Marfan's syndrome [14]. A recent case of a cardiac arrest with postanoxic encephalopathy in a previously healthy 26-year-old man who ingested a very high dose of $32 \mathrm{mg} / \mathrm{kg}$ [34] appears to be an exception from the general association of ibogaine-related deaths or severe cardiac adverse events with medical co-morbidities and co-ingestants, and may indicate a dose-related effect.

Bradycardia importantly potentiates the risk of druginduced TdP [17, 30]. It has been observed in association 
with ibogaine in both animal models [35-38] and humans $[11,16,39,40]$. The mechanism by which ibogaine causes bradycardia remains unknown, and is an interesting and clinically significant toxicological question for future study. Although an older literature suggested inhibition of acetylcholinesterase as a basis for bradycardia, this is not supported by contemporary assay techniques [41]. Ibogaine binds to sodium channels in animal brain tissue with low micromolar affinity [4], and there is an association of sodium channel blockade with bradycardia [42]. However, in human, $\mathrm{Na}_{\mathrm{v}} 1.5$ sodium channels heterologously expressed in TSA-201 cells both ibogaine and 18-MC produce minimal blockade $(>100 \mu \mathrm{M})$ [25].

hERG channel blockade was voltage dependent for all of the compounds tested. Blockade of hERG channels by low-affinity ligands tends to be voltage dependent [43], in contrast to the little or no voltage-dependence commonly exhibited by high-affinity hERG channel blockers.

The data appear to indicate structure-activity relationships regarding positions of substitutions on the ibogamine skeleton and hERG blockade. As indicated in Fig. 1, there are only three positions on the iboga alkaloid structural skeleton that distinguish among the set of iboga alkaloids evaluated in this study. Utilizing the LeMen and Taylor system for numbering the ibogamine skeleton [44, 45], voacangine differs from ibogaine with regard to the carbomethoxy group at the 16 position $\left(\mathrm{R}^{2}\right.$ in the figure). Voacangine and ibogaine show an equivalent effect of hERG antagonism, suggesting that the carbomethoxy group of 18-MC at position 16 is not protective regarding hERG blockade. Ibogaine and voacangine have a methoxy group, and noribogaine has a hydroxyl group at position 10 ( $\mathrm{R}^{1}$ in the figure), and all have comparable hERG antagonism. An oxygen atom could form a noncovalent electrostatic interaction, or in the case of noribogaine, a hydrogen bond with a polar amino acid residue in the binding site of the channel, raising the possibility that oxygen-containing substitutions at position 10 might be a mediator of hERG blockade. 18-MC, in contrast to the other compounds has only a hydrogen at position 10 . The methoxy group at position $18\left(\mathrm{R}^{3}\right.$ in the figure) is another possible structural determinant of the substantially smaller effect of $18-\mathrm{MC}$ on hERG blockade.

The hERG channel binding affinities for the entire set of compounds, including 18-MC fell into a relatively restricted range from 0.71 to $3.89 \mu \mathrm{M}$. Nonetheless, there is a fivefold difference between the top and bottom of this approximately $3 \mu \mathrm{M}$ range. The two compounds at the upper end of this range, voacangine and 18-MC have similar values of $K_{\mathrm{i}}$ of 3.89 and $3.12 \mu \mathrm{M}$, respectively, and share the common attribute of a carbomethoxy group at the same position $16\left(\mathrm{R}^{2}\right.$ in the figure), suggesting that this specific substitution might be a determinant of decreased binding affinity. Interestingly, although this substitution might influence binding affinity, it is not apparently a critical determinant of the effect of hERG blockade, as indicated by the widely divergent values of IC50 for voacangine and 18-MC of 2.25 and $>50 \mu \mathrm{M}$ respectively. 18-MC binds to the hERG channel with an affinity that is within a comparable range to that of the other compounds, but the interaction apparently produces substantially less hERG blockade.

The question of the modulation of hERG blockade by substitutions on the ibogamine skeleton should be addressed further by expanding the query to additional iboga alkaloids in future studies. The apparent structure-activity relationships observed in this study suggest that it may be productive to apply computational biological approaches to investigation of the iboga alkaloid "toxicophore," including in silico modeling of the iboga alkaloid interaction with the hERG channel [46].

In the present study, we used whole-cell patch clamp technique to investigate the potency of hERG blockade by iboga alkaloids. The effect of iboga alkaloids on the gating properties of the hERG channel should be a focus for future study. Future research should extend the model beyond single cells to include interactions among cardiac myocytes using a myocardial wedge preparation, which allows simultaneous recordings of endocardial and epicardial transmembrane action potential in order to evaluate transmural dispersion [47]. The whole animal heart model [48, 49] may be useful approach to the investigation of ibogaine's clinically salient effect of bradycardia, which appears to substantially potentiate the risk of TdP.

\section{Conclusions}

The low micromolar $\mathrm{IC}_{50}$ values of ibogaine and noribogaine appear clinically relevant regarding levels that have been associated with QT prolongation, arrhythmia, and/or fatalities. The prolonged clearance of noribogaine may be a mediating factor in persistent QTc prolongation, arrhythmia, and fatalities at delayed intervals following the ingestion of ibogaine on the order several days. Collectively, the set of iboga alkaloids investigated in this study indicates structure-activity relationships regarding positions on the ibogamine skeleton and hERG blockade, and suggest that this alkaloid class might provide an informative paradigm for investigation of the structural biology of the hERG channel.

Acknowledgements Drs. Rong Bai and Nian Liu were supported by the National Natural Science Foundation of China (NSFC-81370290 and NSFC-81370292). We thank Stevenson Flemer and Bruce O'Rourke from the University of Vermont for HPLC/MS analyses. 
We thank Dr. Maarten E. A. Reith and Dr. Dave Nichols for helpful discussion and Reith Lab for logistical support regarding the research compounds.

\section{References}

1. Bartlett, M. F., Dickel, D. F., \& Taylor, W. I. (1958). The alkaloids of Tabernanthe-Iboga. Part VI. The Structures of ibogamine, ibogaine, tabernanthine and voacangine. Journal of the American Chemical Society, 80, 126-136.

2. Jana, G. K., Paul, S., \& Sinha, S. (2011). Progress in the synthesis of iboga-alkaloids and their congeners. Organic Preparations and Procedures International, 43, 541-573.

3. Alper, K. R. (2001). Ibogaine: A review. The Alkaloids: Chemistry and Biology, 56, 1-38.

4. Glick, S. D., Maisonneuve, I. M., \& Szumlinski, K. K. (2001). Mechanisms of action of ibogaine: Relevance to putative therapeutic effects and development of a safer iboga alkaloid congener. The Alkaloids: Chemistry and Biology, 56, 39-53.

5. Alper, K. R., Lotsof, H. S., \& Kaplan, C. D. (2008). The ibogaine medical subculture. Journal of Ethnopharmacology, 115, 9-24.

6. Vastag, B. (2005). Addiction research. Ibogaine therapy: A 'vast, uncontrolled experiment'. Science, 308, 345-346.

7. Antonio, T., Childers, S. R., Rothman, R. B., Dersch, C. M., King, C., Kuehne, M., et al. (2013). Effect of iboga alkaloids on $\mu$-opioid receptor-coupled $\mathrm{G}$ protein activation. PLOS ONE, 8, e77262.

8. National Institutes of Health. (2014). IND-Enabling Studies and GMP Scale-Up of 18-Methoxycoronaridine Hydrochloride (18 MC) Project Number: 1U01DA034986-01. http://projectreporter. nih.gov/project_info_description.cfm?aid=8448461\&icde $=16047111 \&$ ddparam $=\& d d$ value $=\& d d s u b=\& c r=41 \& c s b=$ default $\& c s=A S C$. Accessed January 05, 2015.

9. Mash, D. C., Kovera, C. A., Pablo, J., Tyndale, R., Ervin, F. R. Kamlet, J. D., \& Hearn, W. L. (2001). Ibogaine in the treatment of heroin withdrawal. The Alkaloids: Chemistry and Biology, 56, $155-171$.

10. Alper, K. R., Lotsof, H. S., Frenken, G. M., Luciano, D. J., \& Bastiaans, J. (1999). Treatment of acute opioid withdrawal with ibogaine. The American Journal on Addictions, 8, 234-242.

11. Alper, K. R., Stajic, M., \& Gill, J. R. (2012). Fatalities temporally associated with the ingestion of ibogaine. Journal of Forensic Sciences, 57, 398-412.

12. Hoelen, D. W., Spiering, W., \& Valk, G. D. (2009). Long-QT syndrome induced by the antiaddiction drug ibogaine. New England Journal of Medicine, 360, 308-309.

13. Pleskovic, A., Gorjup, V., Brvar, M., \& Kozelj, G. (2012). Ibogaine-associated ventricular tachyarrhythmias. Clinical Toxicology, 50, 157.

14. Dettmer, M. R., Cohn, B., \& Schwarz, E. (2013). Prolonged QTc and ventricular tachycardia after ibogaine ingestion [(XXXIII International Congress of the European Association of Poisons Centres and Clinical Toxicologists (EAPCCT)). Clinical Toxicology, 51, 285.

15. Heling, D., Strassburg, C. P., \& Wasmuth, J. C. (2014). Tod nach lbogain-Einnahme- Vergiftung durch Entgiftung (Death after ibogaine consumption-Intoxication by detoxification). Intensivund Notfallbehandlung, 39, 40-43.

16. Shawn, L. K., Alper, K., Desai, S. P., Stephenson, K., Olgun, A. M., Nelson, L. S., \& Hoffman, R. S. (2012). Pause-dependent ventricular tachycardia and torsades de pointes after ibogaine ingestion [2012 Annual Meeting of the North American Congress of Clinical Toxicology (NACCT)]. Clinical Toxicology, 50, 654.
17. Kannankeril, P., Roden, D. M., \& Darbar, D. (2010). Druginduced long QT syndrome. Pharmacological Reviews, 62, 760-781.

18. Sanguinetti, M. C., \& Tristani-Firouzi, M. (2006). hERG potassium channels and cardiac arrhythmia. Nature, 440, 463-469.

19. Koenig, X., Kovar, M., Boehm, S., Sandtner, W., \& Hilber, K. (2014). Anti-addiction drug ibogaine inhibits hERG channels: A cardiac arrhythmia risk. Addiction Biology, 19, 237-239.

20. Thurner, P., Stary-Weinzinger, A., Gafar, H., Gawali, V. S., Kudlacek, O., Zezula, J., et al. (2014). Mechanism of hERG channel block by the psychoactive indole alkaloid ibogaine. Journal of Pharmacology and Experimental Therapeutics, 348, 346-358.

21. Kontrimavičiūte, V., Mathieu, O., Mathieu-Daudé, J. C., Vainauskas, P., Casper, T., Baccino, E., \& Bressolle, F. M. (2006). Distribution of ibogaine and noribogaine in a man following a poisoning involving root bark of the Tabernanthe iboga shrub. Journal of Analytical Toxicology, 30, 434-440.

22. Mash, D. C., Kovera, C. A., Buck, B. E., Norenberg, M. D., Shapshak, P., Hearn, W. L., \& Sanchez-Ramos, J. (1998). Medication development of ibogaine as a pharmacotherapy for drug dependence. Annals of the New York Academy of Sciences, 844, 274-292.

23. Mash, D. C., Kovera, C. A., Pablo, J., Tyndale, R. F., Ervin, F. D., Williams, I. C., et al. (2000). Ibogaine: Complex pharmacokinetics, concerns for safety, and preliminary efficacy measures. Annals of the New York Academy of Sciences, 914, 394-401.

24. Glue, P., Lockhart, M., Lam, F., Hung, N., Hung, C. T., \& Friedhoff, L. (2014). Ascending-dose study of noribogaine in healthy volunteers: Pharmacokinetics, pharmacodynamics, safety, and tolerability. The Journal of Clinical Pharmacology, doi: $10.1002 /$ jcph. 1404 .

25. Koenig, X., Kovar, M., Rubi, L., Mike, A. K., Lukacs, P., Gawali, V. S., et al. (2013). Anti-addiction drug ibogaine inhibits voltagegated ionic currents: A study to assess the drug's cardiac ion channel profile. Toxicology and Applied Pharmacology, 273, 259-268.

26. Huang, X. P., Mangano, T., Hufeisen, S., Setola, V., \& Roth, B. L. (2010). Identification of human Ether-a-go-go related gene modulators by three screening platforms in an academic drugdiscovery setting. Assay and Drug Development Technologies, 8, 727-742.

27. Roth, B. L. (2013). National Institute of Mental Health Psychoactive Drug Screening Program (NIMH PDSP) assay protocol book version II. Chapel Hill, NC: Department of Pharmacology, University of North Carolina at Chapel Hill.

28. Warrick, B., \& Baltarowich, L. (2012). Ibogaine for opioid addiction: A deadly treatment [2012 Annual Meeting of the North American Congress of Clinical Toxicology (NACCT)]. Clinical Toxicology, 50, 656.

29. Jalal, S., Daher, E., \& Hilu, R. (2013). A case of death due to ibogaine use for heroin addiction: Case report. The American Journal on Addictions, 22, 302.

30. Roden, D. M. (1998). Taking the "Idio" out of "Idiosyncratic": Predicting Torsades de Pointes. Pacing and Clinical Electrophysiology, 21, 1029-1034.

31. Cubeddu, L. X. (2009). Iatrogenic QT abnormalities and fatal arrhythmias: Mechanisms and clinical significance. Current Cardiology Reviews, 5, 166-176.

32. Levin, K. H., Copersino, M. L., Epstein, D., Boyd, S. J., \& Gorelick, D. A. (2008). Longitudinal ECG changes in cocaine users during extended abstinence. Drug and Alcohol Dependence, 95, 160-163.

33. Otero-Anton, E., Gonzalez-Quintela, A., Saborido, J., Torre, J. A., Virgos, A., \& Barrio, E. (1997). Prolongation of the QTc 
interval during alcohol withdrawal syndrome. Acta Cardiologica, 52, 285-294.

34. Vlaanderen, L., Martial, L. C., Franssen, E. J. F., van der Voort, P. H. J., Oosterwerff, E., \& Somsen, G. A. (2014). Cardiac arrest after ibogaine ingestion. Clinical Toxicology, 52, 642-643.

35. Dhahir, H. I. (1971). A comparative study on the toxicity of ibogaine and serotonin (p. 163). Bloomington: Indiana University.

36. Glick, S. D., Maisonneuve, I. M., Hough, L. B., Kuehne, M. E., \& Bandarage, U. K. (1999). ( \pm )-18-Methoxycoronaridine: A novel iboga alkaloid congener having potential anti-addictive efficacy. CNS Drug Reviews, 5, 27-42.

37. Binienda, Z. K., Pereira, F., Alper, K., Slikker, W, Jr, \& Ali, S. F. (2002). Adaptation to repeated cocaine administration in rats. Annals of the New York Academy of Sciences, 965, 172-179.

38. Schneider, J. A., \& Rinehart, R. K. (1957). Analysis of the cardiovascular action of ibogaine hydrochloride. Archives Internationales de Pharmacodynamie et de Therapie, 110, 92-102.

39. Mash, D. C., Allen-Ferdinand, K., Mayor, M., Kovera, C. A., Ayafor, J. F., Williams, I. C., et al. (1998). Ibogaine: Clinical observations of safety after single oral dose administrations. In Problems of drug dependence, 1998: Proceedings of the 60th annual scientific meeting, June 12-17 (p. 294). Scottsdale, Arizona: The College on Problems of Drug Dependence, Inc.

40. Samorini, G. (1998). The initiation rite in the Bwiti Religion (Ndea Narizanga Sect, Gabon). Jahrbuch für Ethnomedizin und Bewusstseinsforschung, 6-7, 39-56.

41. Alper, K., Reith, M. E. A., \& Sershen, H. (2012). Ibogaine and the inhibition of acetylcholinesterase. Journal of Ethnopharmacology, 139, 879-882.

42. Kolecki, P. F., \& Curry, S. C. (1997). Poisoning by sodium channel blocking agents. Critical Care Clinics, 13, 829-848.

43. Sanchez-Chapula, J. A., Navarro-Polanco, R. A., Culberson, C., Chen, J., \& Sanguinetti, M. C. (2002). Molecular determinants of voltage-dependent human ether-a-go-go related gene (HERG) $\mathrm{K}+$ channel block. Journal of Biological Chemistry, 277, 23587-23595.

44. Le Men, L., \& Taylor, W. I. (1965). A uniform numbering system for indole alkaloids. Experientia, 21, 508-510.

45. Alper, K. R., \& Cordell, G. A. (2001). A note concerning the numbering of the iboga alkaloids. In Ibogaine: Proceedings of the first international conference (also published as The Alkaloids Chemistry and Biology Vol. 56) (Alper, K. R., Glick, S. D., \& Cordell, G. A., eds), pp. xxiii-xxiv. San Diego: Academic Press.

46. Coi, A., Massarelli, I., Testai, L., Calderone, V., \& Bianucci, A. M. (2008). Identification of "toxicophoric" features for predicting drug-induced QT interval prolongation. European Journal of Medicinal Chemistry, 43, 2479-2488.

47. Yan, G. X., Wu, Y., Liu, T., Wang, J., Marinchak, R. A., \& Kowey, P. R. (2001). Phase 2 early afterdepolarization as a trigger of polymorphic ventricular tachycardia in acquired longQT syndrome : Direct evidence from intracellular recordings in the intact left ventricular wall. Circulation, 103, 2851-2856.

48. Bai, R., Lu, J. G., Pu, L., Liu, N., Zhou, Q., Ruan, Y. F., et al. (2005). Left ventricular epicardial activation increases transmural dispersion of repolarization in healthy, long QT, and dilated cardiomyopathy dogs. PACE-Pacing Clinical Electrophysiology, 28, 1098-1106.

49. Wang, L., Lu, J., Zhang, F., Bai, R., \& Wang, L. (2006). Effects of amiodarone on transmural dispersion of ventricular effective refractory periods across myocardial layers in the normal and hypertrophic canine heart. Journal of Huazhong University of Science and Technology. Medical sciences = Hua zhong ke ji da хие хие bao. Yi xue Ying De wen ban = Huazhong keji daxue xuebao. Yixue Yingdewen ban, 26, 182-184. 